\title{
POLA ASUH ORANG TUA DALAM MOTIVASI BELAJAR ANAK
}

\author{
Wardatul Asfiyah \\ Mahasiswa UIN Sunan Kalijaga Yogyakarta \\ warda.asfiyah@gmail.com
}

\begin{tabular}{ll}
\hline Abstrak & The process of interaction between \\
\hline Article History & parents and children includes \\
Received : 15 Oktober 2019 activities such as educating, \\
Revised : 19 Oktober 2019 activing \\
Accepted:23 Oktober 2019 maintaining, protecting and directing \\
\hline Keywords : & children's behavior. During \\
Parenting, Motivation & development, children learn from \\
& their parents. Parents teach various \\
& things to their children ranging from \\
& talking, walking and so forth. This \\
& article aims to describe parenting \\
& patterns in motivating children's \\
& learning. The method used in this \\
& paper is the library research method. \\
& The results of this study indicate that \\
the motivation of children will be & good if the parenting is done by good \\
parents. The better parenting that & parents do, the better the child's \\
motivation to learn. Authoritative & parenting (parenting that really gives \\
attention to their children) becomes \\
one of good parenting in fostering \\
children's learning motivation than \\
otherparenting.
\end{tabular}

\section{Pendahuluan}

Di era yang serba dengan kecanggihan teknologi, sangat mempengaruhi belajar anak. Anak merupakan calon penerus bangsa, seorang yang akan mengembangkan dan memajukan bangsa di masa depan. Masa depan anak akan menjadi tertata jika belajar anak baik. Belajar merupakan salah satu penunjang bagi anak untuk mewujudkan cita-cita di masa depan. Dengan semangat belajar maka 
seorang anak dengan mudah akan mendapatkan apa yang ia citacitakan.

Pendidikan merupakan suatu yang sangat penting untuk menunjang masa depan anak. Orang tua merupakan guru pertama dan utama dalam membimbing, mengajar dan memberikan pendidikan pada anak.Sebagai seorang yang pertama memberikan contoh pada anak, maka penting bagi orang tua untuk menumbuhkan motivasi dalam diri anak.Dalam zaman yang penuh dengan kecanggihan ini banyak orang tua yang lalai dalam memberikan pendidikan kepada anaknya sehingga banyak anak yang bermalas-malasan dan akibatnya motivasi belajar pada anak menurun.

Motivasi belajar merupakan bentuk pentingnya pendidikan yang diberikan oleh orang tua.Ada dua bentuk motivasi yaitu ekstrinsik (dari luar diri) dan intrinsik (dari dalam diri) (John W. Santrock, 2011: 514).Salah satu yang dapat mempengaruhi motivasi ekstrinsik adalah orang tua.Namun sayangnya banyak orang tua yang menyerahkan pendidikan kepada sekolah tanpa memberikan perhatian yang lebih pada anaknya ketika berada di sekolah.Padahal seharusnya orang tua memberikan perhatian dan motivasi kepada anaknya agar supaya anak lebih semangat dalam belajar.Karena dalam suatu penelitian menunjukkan bahwa ada pengaruh positif antara perhatian orang tua tehadapa motivasi belajar anak (Nina Isnawati dan Dhyah Setyorini, 2012: 27-47).Untuk itu pentingnya perhatian orang tua untuk meningkatkan motivasi belajar anak.

Gaya asuh merupakan salah satu cara dalam meningkatkan motivasi belajar anak. Akan tetapi ada beberapa bentuk gaya asuh yang dapat memberikan efek untuk memotivasi anak. Untuk itu orang tua harus memahami gaya asuh ini agar pengasuhan yang dilakukan oleh orang tua dapat berefek positif dalam peningkatan motivasi pada anak. Dalam tulisan ini penulis mengkaji tentang gaya asuh orang tua dalam motivasi anak. Penulis bermaksud untuk memberikan penjelasan tentang pola asuh yang tepat untuk meningkatkan motivasi belajar anak.Sehingga orang tua nantinya tidak salah dalam memberikan pengasuhan maupun pendidikan terhadap anaknya.

\section{Metode Penelitian}

Metode yang digunakan dalam kajian ini mengguakan metode atau pendekatan kepustakaan (library research) dengan menggunakan metode analisis deskriptif, yaitu dengan jalan 
mengumpulkan data, menyusun atau mengklarifikasi, menyusun dan menginterpretasinya (Surakhmad, 1980:147).

Penelitian ini juga mendasarkan kepada studi kepustakaan (library research). Library research adalah serangkaian kegiatan yang berkenaan dengan metode pengumpulan data pustaka, membaca dan mencatat serta mengolah bahan penelitiannya seperti buku-buku referensi dan hasil penelitian sejenis sebelumnya yang pernah dilakukan oleh orang lain. Tujuannya ialah untuk mendapatkan landasan teori mengenai masalah yang diteliti. (Mustika Zed, 2014: 2-3).

Studi pustaka atau kepustakaan juga dapat diartikan sebagai serangkaian kegiatan yang berkenaan dengan metode pengumpulan data pustaka, membaca dan mencatat serta mengolah bahan penelitian. Pengumpulan data dalam penelitian ini dilakukan dengan menelaah dan/atau mengeksplorasi beberapa Jurnal, buku, dan dokumen-dokumen (baik yang berbentuk cetak maupun elektronik) serta sumber-sumber data dan informasi lainnya yang dianggap relevan dengan penelitian atau kajian (Supriadi, 2016: 84).

\section{Pembahasan}

\section{Konsep Motivasi Belajar}

Secara umum orang menyamakan antara kata "motivasi" dengan kata "motif" untuk merujuk mengapa seseorang itu berbuat sesuatu.Motif manusia merupakan dorongan, keinginan, hasrat, dan tenaga penggerak lainnya yang berasal dari dalam dirinya, untuk melakukan sesuatu.Berawal dari kata "motif" itu, maka motivasi dapat diartikan sebagai daya penggerak yang telah menjadi aktif. Maka dapat dikatakan motivasi akan menyebabkan terjadinya suatu perubahan energy yang ada pada diri manusia, sehingga akan bergayut dengan persoalan gejala kejiwaan, perasaan dan juga emosi, untuk kemudian bertindak untuk melakukan sesuatu (Noer Rahmah, 2012: 239-240).

Seseorang berbuat sesuatu atau melakukan sesuatu didorong oleh sebuah kekuatan dari dalam dirinya.Dorongan dari dalam diri seseorang dalam melakukan sesuatu disebut motif (Eva Latipah, 2012: 158).Sedangkan motivasi adalah keinginan yang mendorong semua tindakan dan merupakan pelopor sekaligus batu penjuru bagi pembelajaran (Ostroff W.L, 2003: 7). Motivasi menurut Santrock adalah proses yang member semangat, arah dan kegigihan perilaku. 
Sedangkan belajar menurut Gegne (1984) didenifisikan sebagai suatu proses dimana suatu organisasi berubah perilakunya sebagai akibat pengalaman(Ratna Wilis Dahar: 2011: 2).Menurut Passer (2009) belajar merupakan perubahan perilaku yang relative permanen sebagai akibat dari adanya latihan (Eva Latipah, 2012: 69).Motivasi adalah motivasi belajar siswa, yaitu dorongan atau kemauan siswa untuk melakukan aktivitas belajar agar prestasi belajar dapat dicapai (Nina Isnawati dan Dhyah Setyorini, 2012: 34). Jadi dari definisi diatas dapat disimpulkan bahwa Motivasi belajar adalah suatu proses yang mendorong anak untuk melakukan perubahan dari perilakunya.

Masih banyak yang beranggapan bahwa motivasi tidak begitu penting dalam suatu pembelajaran, faktor strategi gurulah yang penting untuk meningkatkan pembelajaran.Dalam penelitian alsa dikutip dari Eva Latipah bahwa para siswa di Yogyakarta memiliki prestasi matematika yang tinggi, mereka ternyata dengan motivasi belajar yang tinggi.Tidak sebatas itu motivasi mereka ternyata diiringi dengan penggunaan strategi yang sesuai dalam belajar matematika (Eva Latipah, 2012: 160). Menurut Wendy ada beberapa pendorong motivasi belajar anak yaitu:

a. Pembiasaan dan kesukaan akan hal-hal baru

Pembiasaan sebuah sifat mendasar dari system syaraf member mekanisme untuk tidak mempedulikan lingkungan saat lingkungan tidak menyajikan ancaman atau imbalan mendesak, dan memusatkan perhatian pada masukan baru yang berpotensi penting.Pembelajaran dianggap sesuatu yang paling sedderhana dari pembelajaran.pembiasaan penting untuk difahamidalm kaitannya dengan motivasi anak-anak, karena jika anak-anak terbiadsa dengan situasi pembelajaran dalam ruang kelas, perhatian dan minat mereka akan menurun (Wendy L. Ostroff, 2013: 9).

b. Kepercayaan diri

Kepercayaan diri membantu anak-anak belajar. Sebagai orang dewasa, kita sering kali cukup tahu dimana kemampuan terbaik kita, apa yang mampu kia lakukan dengn mudah dan alamiah. Kepercayaan diri akan kemampuan diri sendiri, menjadi langkah utama menuju keberhasilan. Di sisi lain, jika kita mendapatkan pengalaman negatif dengan pembelajaran, kita mungkin akan melabeli diri sendiri sebagai tidak mampu dalam subjek tersebut. Pada saat kita percaya bahwa kita tidak bisa 
melakukan sesuatu, tidak peduli sekeras apa kita berusaha, kita akan menyerah dalam waktu yang lama (Wendy L. Ostroff, 2013: 15). Pentingsekali dalam membangun kepercayaan diri anak-anak. Dalam penelitian yang sekarang dianggap klasik oleh San Fransisco dan Psikolog Universitas California (Rosenthal dan Jacobson, 1996) guru-guru sekolah dasar diberitahu bahwa 20 persen dari para siswa mereka menunjukkan potensi keberhasilan akademis yang luar biasa hanya karena dibangaun dalam biri siswa suatu kepercayaan diri akan kemampuan mereka sendiri (Wendy L. Ostroff, 2013: 19).

c. Bermain

Bermian merupakan tatanan yang alamiah dan spontan untuk pembelajaran. Anak-anak cenderung menggunakan permainan sebagai cara untuk menyelidiki dan berdaya cipta, kreatif, dan pensaran. Bermain merupakan kegiatan membunuh waktu mereka, kegiatan yang memakan sebagaian besar waktu dan energy dan terus menerus menyerap serta menggairahkan mereka.Kegiatan emmotivasi dari bermain tidak bisa disepelekan (Wendy L. Ostroff, 2013: 25). Menurut Vigotsky (1978) pengendalian terbesar seorang akan timbul selama bermain, karena bermain memerlukan tindakan yang menantang pengetahuan duni-nyata. Seorang anak harus mengesampingkan apa yang sudah diketahuinya tentang sebatang tongkat, untuk memungkinkan tongkat itu menjadi seeor kuda, misalnya. Karena bermain berdasarkan definisinya terbebaskna dari konsekuensidunia-nyata, anak-anak dalam bermain bisa bebas bereksperimen dan mengambil resiko yang mungkin tidak akan mereka lakukan dalam situasi yang berbeda. Resiko-resiko seperti itu penting bagi pembelajaran (Wendy L. Ostroff, 2013: 27).

d. Bergabung dengan komunitas

Manusia telah berevolusi dalam msyarakat dan keinginannya untuk menjadi bagian dari mereka merupakan sesuatu yang menjadi kebutuhan mendasar. Malahan, sekarang banyak imuan syaraf yang mepertimbangkan otak manusia sebagai "alat sosial", berarti bahwa keahlian pemahaman kita beradaptasi dan berfungsi untuk melayani hubungan-hubungan social (Wendy L. Ostroff, 2013: 29). 
Keinginan untuk bergabung dengan komunitas merupakan motivator yang begitu mendalam untuk belajar, hingga pemebelajaran seumur hidup kita sering kali timbul bahkan tanpa kita sadari.Kejadian-kejadian sehari-hari dalam hidup kita bisa mengungkapakn kekuatan motivasi untuk belajar dan kekuatan penggabungan dalam masyarakat sabagi motivasi.Kuatnya tarikkan otivasi untuk bergabung dengan masyarakat, bisa mendorong bayi dan anak-anak dalam bentuk pembelajaran yang rumit. Misalnya, perkembangan berjalan merupakan tonggak sejarah yang motorik yang rmuit dan melibatkan keharusan memiliki kekuatan yang cukup untuk menaggung berat tubuh seseorang pada satu kaki (sementara kaki yang lain melangkah maju) dan memiliki pengedalian postural yang cukup agar tubuh tetap seimbang. Ini membutuhkan banyakk waktu dna usaha untuk dipelajari, tapi keiginan untuk bergabung dengan masyarakant yang berjalan sudah menjadi motivasi yang cukup untuk mempelajari proses pembelajaran tersebut. Penelitian menunjukkan bahwa anak-anak yang memiliki kakak yang lebih cepat berjalan daripada mereka yang tidak terlepas dari tinggi, berat dan jenis kelamin (berger, 2006). Berjalan cenderung dimulai pada saat yang kurang lebih sama sewaktu bayi mulai memahami dan mendapat keuntungn dari akses ke dunia social (Wendy L. Ostroff, 2013: 40).

Menurut Iskandar (2009) ada beberapa peran motivasi yang penting dalam belajar dan pembelajaran (Noer Rahmah, 2012: 243-244) adalah:

a. Peran motivasi dalam penguatan belajar

b. Usaha untuk memberi bantuan dengan rumus matematika dapat menimbulkan penguatan belajar.

c. Peran motivasi dalam memperjelas tujuan belajar

d. Peran motivasi menentukan ketekunan dalam belajar

\section{Motivasi Intrinsik dan Ekstrinsik}

Motivasi dapat timbul dari luar maupun dari dalam diri individu itu sendiri.Motivasi yang berasal adri luar individu diberikan oleh motivator seperti orang tuanya, guru, konselor, ustad/ustadzah, orang sekat atau teman dekat, dan lain-lain. Sedangkan motivasi yang berasal atau timbul dari dalam seseorang dapat disebsbkan seseorang 
mempunyai keinginan untuk dapat menggapai sesuatu (cita-cita) atau lain sebagainya.

Berdasarkan hal tersebut motivasi terbagi atas dua macam yaitu intrinsik dan Ektrinsik.Motivasi Intrinsik yaitu motif-motif yang menjadi aktif atau berfungsinya tidak perlu dirangsang dari luar, karena dalam diri setiap individu sudah ada dorongan untuk melakukan sesuatu. Contoh seseorang yang senang membaca tidak ada yang menyuruh maka ia akan rajin membaca (Noer Rahmah, 2012: 254).Motivasi intrinsik adalah kecenderungan alamiah untuk mencari dan menaklukkan tantangan ketika kita mengajar kepentingan pribadi dan menerapkan kapabilatas.Bila kita termootivasi secara intrinsic, kita tidak membutuhkan insentif atau hukuman karena kegiatan itu sendiri merupakan rewarding.

Motivasi Ekstrinsik yaitu motif-motif yang aktif dan berfungsinya karena adanya perangsang dari luar. Sebagai contoh seseorang itu belajar, karena tahu besok paginya akan ujian dengan harapan mendapatkan nilai baik, sehingga mendapatkan pujian, sanjungan dan lain-lain (Noer Rahmah, 2012: 255). Ketika siswa bertambah dewasa, mereka semakin ingat pentingnya nilai yang baik (metode ekstrinsik), dan penerimaan di perguruan yang tinggi, sehingga mereka berfokus untuk memperoleh rata-rata nilai yang tinggi.Motivasi ekstrinsik tidak selalu buruk.Siswa sering kali termotivasi secara bersamaan yaitu oleh motivasi intrinsic dan ekstrinsik.Motivasi ekstrinsik mungkin merupakan satu-satunya hak yang dapat membuat siswa antusias mengikuti pembelajaran dikelas secara sukses dan terlibat dalam prilaku yang produktif. Namun demikian, motivasi intrinsiklah yang akan bertahan lama dalam diri seseorang dalam jangka panjang. Motivasi intrinsic akan mendorong mereka emmahami dan menerapkan apa yang telah dipelajari, serta menjaga keinginan mereka untuk terus membaca dan belajar belajar tentang berbagai hal bahkan setelah mereka lulus sekolah (Eva Latipah, 2012: 176).

\section{Peran Motivasi Dalam Mencapai Keberhasilan Belajar}

Motivasi belajar merupakan faktor psikis yang bersifat non intektual.Peranannya yang khas adalah dalam penumbuhan gairah, perasaan dan semangat untuk belajar.Motivasi belajar adalah dorongan yang menjadi penggerak dalam diri seseorang untuk melakukan sesuatu dan mencapai suatu tujuan yaitu untuk 
berprestasi.Dengan demikian, motivasi memiliki peran strategis dalam belajar, baik pada saat memulai belajar, saat sedang belajar, maupun saat berakhirnya belajar.Agar perannya lebih optimal, maka prinsip-prinsip motivasi dalam aktivitas belajar haruslah dijalankan. Prinsip-prinsip motivasi adalah:

a. Motivasi sebagai penggerak yang mendorong aktivitas belajar

b. Motivasi intrinsic lebih utama dari pada motivasi ekstrinsik dalam belajar

c. Motivasi berupa pujian lebih baik dari pada hukuman

d. Motivasi berhubungan erat dengan kebutuhan belajar

e. Motivasi dapat memupuk optimism dalam belajar

f. Motivasi melahirkan prestasi dalam belajar(Nyanyu Khadijah, 2014: 157)

Selain itu menurut Purwa Atmaja ada beberapa fungsi motivasi dalam belajar.Pertama, motif bersifat mengarahkan dan mengatur tingkah laku individu. Motif di dunia nyata digambarkan pembimbing pengarah pengorientasi suatu tujuan tertentu dari individu. Tingkah individu kikatakan bermotif jika bergerak kearah tertentu. Dengan demikian, suatu motif dipastikan punya tujuan tertentu, mengandung ketekunan dan kegigihan dalm bertindak. Kedua, Motif sebagai penyeleksi tingkah laku individu. Motif yang dipunyai atau terdapat pada diri individu membuat individu yang bersangkutan bertindak secara terarah kepada suatu ujuan yang terpilih yang telah diniatkan oleh individu tersebut. Ketiga, Motif member energy dan tingkah laku individu. Motif diketahui sebagai daya dorong dan peningkatan tenaga sehingga terjadi perbuatan yang tampak apada organism. Motif juga mempunyai fungsi untuk mempertahankan atau perbuatan atau minat agar dapat berlangsung terus menerus dalam jangka waktu lama (Purwa Atmaj Prawira, 2013: 321-322).

\section{Pola Asuh Orang Tua}

Pola Asuh adalah suatu proses interaksi antara orang tua dan anak yang meliputi kegiatan sepeti memeilihara, melindungi dan mengarahkan tingkah laku anak selama masa perkemabangan anak tersebut (Winanti Siwi Rspati, 2006: 119). Para orang tua dapat mempengaruhi kepribadian anak-anak mereka secara Anak-anak tumbuh dalalm keluarga yang berbeda-beda. beberapa orang tua mengasuh dan mendukung anaknya. orang rua lainnya bersikap kasar 
atau mengabaikan anaknya. beberapa orang tuanya bercerai. Anak lainnya tinggal dalam keluarga yang orang tuanya tiidak pernah bercerai. anak lainnya ikut keluarga angkat. Beberapa ayah ibu bekerja seharian dan menempatkan anaknya dalam kegiatan sekolah tambahan atau kursus. ayah dan ibu dari anak lainnya mungkin sudah ada di rumah ketika anak-anak pulang dari sekolah. beberapa anak tumbuh di lingkungan yang seragam etnisnya, yang lainnya dalam lingkungan etnis yang bercampur-campur. beberapa anak hidup dalam kemiskinan, yang lainnya berkecukupan. ada anak yang punya saudara kandung ada juga yang tidak. situasi yang sangat bervariasi ini akan mempengaruhi murid didalam dan di luar kelas (John W. Sntrock, 2012: 90).

Keluarga merupakan lingkungan pertama yang paling berpengaruh pada kehidupan anak sebelum kondisi di sekitar anak (Masyarakat dan sekolah).Hmapir 75\% waktu anak habis dalam keluarga.Mulai bangun tidur hingga kembali beristirahat keluargalah yang ada disekitarnya. Seorang anak yang dilahirkan dari keluarga yang berprofesi seorang guru tentu beda dengan seorang anak yang keluarganya berprofesi sebagai pedagang. begitu pula denga seorang wartawan ataupun penulis. anak cenderung mengikuti apa yang ada dalam keluarga. meskipun tidak selalu seperti itu, seperti pepatah bilang "Buah jatuh tidak jauh dari pohonnya". Dalam keluarga yang dapat mempengaruhi tingkat kecerdasan atau hasil belajar pada anak antara lain: cara mendidik anak, relasi antar anggota keluarga, suasana rumah, keadaan ekonomi, pengertian orang tua serta latar belakang kebudayaan (John W. Santrock, 2012: 64).

Anak-anak tumbuh dalam keluarga yang berbeda-beda. Beberapa orang tuan mengasuh dan mendukung anak mereka. Orang tua lainnya bersikap kasar dan mengabaikannya. Ada beberapa jenis pola asuh orang tua menurut Santrock:

a. Authotarian Parenting, adalah gaya asuh yang bersifat membatasi dan menghukum. Orang tua yang otoriter memerintahkan anaknya untuk mengikuti petunjuk mereka dan menghormati mereka. Mereka membatasi dan mengontrol anak mereka dan tidak mengijinkan anak mereka banyak cakap. Menurut Bee \& Boyd yang dikutip oleh Winanti Siwi dkk bahwa Pola asuh ini lebih menekankan pada kebutuhan orang tua, sedangkan ekspresi diri dan kemandirian anak ditekan atau dihalangi.Orang tua yang menggunakan pola asuh authoritarian 
sangat menekankan konformitas dan ketaatan mutlak. Orang tua juga sering menggunakan hukuman sebagai cara membentuk kepatuhan anak. Anak yang dibesarkan dari pola pengasuhan seperti ini biasanya memiliki kecenderungan emosi tidak stabil (moody), murung, takut, sedih, dan tidak spontan. Selain itu anak yang dibesarkan dalam keluarga ini akan lebih pasif, tidak mandiri, kurang terampil bersosialisasi, penuh dengan konflik, kurang percaya diri, dan kurang memiliki rasa ingin tahu. Jika anak frustasi, maka ia cenderung bereaksi memusuhi teman sebaya. Anak laki-laki yang orang tuanya berpola asuh authoritarian, akan menjadi anak mudah marah dan bersikap menentang, sedangkan pada anak perempuan akan menjadi sangat tergantung dan kurang dalam bereksplorasi, serta menghindari tugas-tugas menantang (Winanti Siwi, 2006: 129).

b. Authoritative Parenting, adalah mendorong anaknya untuk menjadi independen tetapi masih membatasi dan mengontrol tindakan anaknya. Perbincangan tukar pendapat boleh dan orang tua bersikap membimbing dan mendukung. Orang tua yang otoritative mungkin akan merangkul anaknya dengan lemah lembut dan berkata, "kamukan tahu seharusnya kamu tidak boleh melakukan itu." Orang tua membuat aturan jelas dan konsisten serta menerapkan standar tingkah laku yang diharapkan dari anak. Peraturan yang diberikan orang tua disertai dengan penjelasan dan penalaran kepada anak mengapa suatu peraturan dibuat, dan mengapa anak diharapkan untuk bertingkah laku tertentu. Terdapat saling memberi dan menerima antara orang tua dan anak, sehingga anak memperoleh kesempatan untuk mengemukakan pendapat kepada orang tua dan mengikutsertakananak dalam diskusi (Winanti Siwi, 2006: 130).

c. Neglectful Parenting adalah gaya asuh dimana orang tua tidak terlibat aktif dalam kehidupan anaknya, ketika anak menjadi remaja atau bahkan masih kecil. Anak dari orang tua yang abai ini sering bertindak tidak kompeten secara sosial. Mereka cenderung kurang bisa mengontrol diri, tidak cukup mandiri dan tidak termotivasi untuk berprestasi.

d. Indulgent Parenting, gaya asuh dimana orang tua selalu terlibat dalam kehidupan anaknya tetapi tidak dapat memberi batasan atau kekangan pada perilaku mereka. Orang tua ini selalu memberikan kebebasan kepada anaknya tanpa mengekang si 
anak. Hasilnya si anak biasanya tidak belajar untuk mengontrol perilakunya sendiri. Orang tua ini tidak memperhitungkan seluruh aspek perkembangan anak (John W. Santrock, 2012: 91).

\section{Pola Asuh Orang Tua dan Motivasi Belajar}

Orang tua, guru dan teman sebaya adalah orang-orang ynag sangat penting dalam dunia sosial anak dan hubungan mereka dengan anak dapat memperkuat dan melemahkan dalam pembelajaran anak (John W. Santrock, 2012: 487). Menurut Muhibbin Syah, mengatakan bahwa salah satu faktor yang mempengaruhi belajar adalah motivasi siswa. Kekurangan atau ketiadaan motivasi, baik yang bersifat internal maupun eksternal akan menyebabkan kurang bersemangatnya siswa dalam melakukan proses mempelajari materimateri pelajaran baik di sekolah maupun di rumah. Salah satu faktor yang mempengaruhi motivasi belajar ini adalah keluarga yang dalam hal ini adalah pola asuh orang tua. Sifat orang tua terhadap anak, praktek pengelolaan keluarga, ketegangan dalam keluarga, semuanya dapat member dampak baik maupun buruk terhadap kegiatan belajar siswa.Contoh kegiatan yang diterapkan orang tua siswa dalam mengelola keluarga (family management practices) yang keliru, seperti kelalaian orang tua dalam memonitor kegiatan anak dapat menimbulkan dampak lebih buruk lagi. Dalam hal ini bukan saja anak tidak mau belajar melainkan juga ia cenderung berperilaku menyimpang, terutama perilaku menyimpang yang berat seperti antisocial(Muhibbin Syah, 2005: 152).

Menurut Siska Eko Mawarsih dkk, ada hubungan positif antara perhatian orang tua dan motivasi belajar terhadap prestasi belajar (Siska Eko, 2013: 13). Penelitian ini mendukung penelitian sebelumnya yang dilakukan oleh Siti Tsaniatul Hidayah bahwa terdapat hubungan yang positif antara pola pengasuhan yang diberikan orang tua terhadap motivasi belajar siswa. Dimana apabila pola asuh yang diberikan pada siswa meningkat $1 \%$ maka akan diikuti pula peningkatan motivasi belajar siswa sebesar $0,555 \%$, dimana semakin baik pola asuh semakin baik pula motivasi belajar siswa(Siti Tsaniyaul Hidayah, 2012: 66).

Hasil penelitian ini juga didukung oleh penelitian sebelumnya yang dilakukan oleh Dyah Retno dan Aryani Tri bahawa Berdasarkan hasil analisis data penelitian, diperoleh koefisien korelasi dua variabel bebas yaitu 0,453 dengan taraf signifikansi 0,042. Maka dapat 
disimpulkan bahwa ada korelasi antara motivasi berprestasi dan persepsi terhadap pola asuh orangtua dengan prestasi belajar (Dyah Retno dan Aryani Tri, 2013: 1-6). Ini menunjukkan bahwa pentingnya pola asuh yang dilakukan oleh orang tua untuk memotivasi belajar anak. Karena semakin baik pola asuh yang dilakukan orang tua maka akan berpengaruh terhadap prestasi anak.

\section{Simpulan}

Pola asuh adalah suatu proses interaksi antara orang tua dan anak yang meliputi kegiatan sepeti mendidik, memelihara, melindungi dan mengarahkan tingkah laku anak. Selama masa perkembangan anak tersebut belajar yang lakukan oleh orang tua terhadap anaknya sudah cukup menunjukkan usaha mendukung dalam menumbuhkan motivasi anak.Ada beberapa pola asuh macam pola asuh diantarany otoriter, otoritative, orang tua yang abai, dan orang tua yang memanjakan anak.Motivasi belajar menjadi sallah satu tugas dari orang tua.Ada dua macam motivasi yaitu intrinsic dan ekstrinsik.Motivasi ekstrinsik adalah motivasi yang salah satunya dapat dipengaruhi oleh pola asuh yang dilakukan olehorang tua. Motivasi anak akan menjadi baik jika pola asuh yang dilakukan oleh orang tua baik atau tidak membuat anak tertekan. Semakin baik pola asuh yang dilakukan orang tua maka akan semakin baik pula motivasi belajar anak. Pola asuh yang otoritative (pola asuh yang sangat memberikan perhatian kepada anaknya) menjadi salah satu pola asuh yang dapat meningkatkan motivasi anak dari pada pola asuh yang lain. 


\section{DAFTAR PUSTAKA}

Dyah Retno dan Aryani Tri, "Hubungan Antara Motivasi Berprestasi dan PersepsiTerhadap Pola Asuh Orangtua Dengan Prestasi Belajar" Jurnal Psikologi Pendidikan dan Perkembangan, Vol. 2, No. 1, April 2013.

Latipah, Eva. 2012. Pengantar Psikologi Pendidikan. Pedagogja: Yogyakarta.

Santrock,John W. 2011. Psikologi Pendidikan, Kencana: Jakarta.

Syah, Muhibbin. 2005. Psikologi Belajar, Raja Grafindo Persada: Jakarta.

Nina Isnawati \& Dhyah Setyorini. 2012. "Jurnal Pendidikan Akuntansi Indonesia", Vol. X, No. 1.

Rohmah, Noer. 2012. Psikologi Pendidikan, Teras: Yogyakarta.

Khodijah,Nyanyu, 2014. Psikologi Pendidikan, Rajawali Press: Jakarta.

Ostroff, W. L. 2003. Memahami Cara Anak-Anak Belajar,Indeks: Jakarta Barat.

Prawira,Purwa Atmaja. 2013. Psikologi Pendidikan dalm Perspektif, Ar-Ruzz Media :Yogyakarta.

Dahar,Ratna Wilis. 2011. Teori-Teori Belajar dan Pembelajaran, Erlangga: Jakarta.

Siska Eko dkk, 2013."Pengaruh Perhatian Orang Tua dan Motivasi Belajar Terhadap Prestasi Belajar", JUPE UNS, Vol. 1, No. 3.

Hidayah, Siti Tsaniatul. 2012. "Hubungan Pola Asuh Orang Tua Dengan Motivasi Belajar Siswa", UIN Sunan Kalijaga: Yogyakarta.

Ostroff, Wendy L. 2013. Memahami Cara Anak-Anak Belajar, Indeks: Jakarta.

Winanti Siwi Respati dkk, 2006. "Perbedaan Konsep Diri Antara Remaja Akhir yang Mempersepsi Pola Asuh Orang Tua", Jurnal Psikologi, Vol 4, No. 2.

Winarno Surakhmad. 1980. Pengantar Interaksi Mengajar- 
50 Wardatul Asfiyah, Pola Asuh Orang Tua dalam Motivasi,.....

Belajar Dasar-dasar dan Teknik Metodologi pengajaran. Tarsito: Bandung

Mustika Zed, 2004. Metode Penelitian Kepustakaan, Yayasan Obor Nasional: Jakarta. 